\title{
MICROFINANZAS, O FUTURO PASA POLA BANCA COMERCIAL
}

José Manuel SASTRE CENTENO*

Elena INGLADA GALIANA

Facultade de Ciencias Económicas y Empresariales. Universidade de Valladolid Resumo: As microfinanzas, dende os seus inicios na segunda metade do século XX, percorreron un longo camiño para chegar a converterse no sistema financeiro dos máis necesitados, dos pobres, tanto nos países máis pobres como nas nacións prósperas. A través dos diversos servizos que ofrecen, especialmente os microcréditos, fixeron posible unha saída da pobreza a un gran número dos máis necesitados e o acceso a obxectivos antes imposibles de acadar como a educación dos fillos, a sanidade, a seguridade social e un mellor futuro fóra do círculo vicioso da pobreza. Na actualidade, as características dos factores que configuraron as primeiras entidades microfinanceiras cambiaron. O financiamento, que se apoiaba nunha primeira etapa nas subvencións dos organismos financeiros internacionais ou dos gobernos, están evolucionando cara a un financiamento propio sustentado polos beneficios e os aforros dos clientes. Os pobres resultaron ser extraordinarios clientes tanto por ser cumpridores cos seus compromisos, como por ter disciplina de aforro, especialmente as mulleres, que son o grupo máis numeroso e responsable dos microcréditos. Neste contexto, as microfinanzas aparecen como un subsector rendible e, consecuentemente, a banca comercial con financiamento propio e capacidade de expansión, viu nesta contorna unha posibilidade de ampliar o seu negocio, desembarcando con toda a súa capacidade financeira. Neste momento estanse desenvolvendo movementos de intervención da banca comercial en todos os mercados das microfinanzas. O futuro parécenos claro, outro problema son os obxectivos. Para as microfinanzas clásicas, un dos valores que implicaban rendibilidade, era o apoio para rachar co círculo vicioso da pobreza. Hai unha forte dúbida sobre se a banca comercial tamén o considera un valor contable.

\section{1.- INTRODUCIÓN.}

As microfinanzas son un produto pensado e dirixido aos pobres co obxectivo de facer posible unha mellora económica e educativa que lles permita saír da pobreza e crear un futuro para eles e as súas familias. Os pobres están inmersos nos que Nurske (1907-1959) denominou o "círculo vicioso da pobreza" que consiste en que os ingresos dos pobres só poden cubrir as necesidades máis básicas, non sempre todas, pero non lles posibilita ningunha capacidade de aforro, e por iso, as súas posibilidades de capitalizar calquera microempresa que poida sacarlles da miseria é imposible. É máis, a incapacidade sequera de cubrir todas as súas necesidades, especialmente as ocasionais derivadas dunha doenza ou dun desastre natural, por exemplo, lévalles inexorablemente a endebedarse con usureiros que lles cobran uns intereses abusivos que se converten nunha carga para sempre porque son incapaces de devolver o capital.

\footnotetext{
* José Manuel Sastre Centeno, e-mail: manolo@eco.uva.es, Elena Inglada Galiana, e-mail: elenaig@eco.uva.es. Profesores de Contabilidad. Departamento de Economía Financiera y Contabilidad. Facultad de Ciencias Económicas y Empresariales Avenida del Valle Esgueva ํㅜ 6. 47011 Valladolid (España)
} 
Neste contexto é onde aparecen as microfinanzas ${ }^{1}$ como unha solución e, ao mesmo tempo, como un motor económico que dinamiza non só ás persoas e familias, senón á economía da zona na que se desenvolven. O sistema de traballo das microfinanzas consiste en proporcionar pequenos créditos aos pobres para que financien unha microempresa na que traballa o prestatario ou a súa familia máis próxima. Certo que hai tipos diferentes de prestacións: existen sistemas comunais de riscos, de maneira que o empréstito realízase a un conxunto de persoas e todas responden subsidiariamente, créditos mancomunados, créditos con avais, etc., pero os máis estendidos e coñecidos baséanse máis ben na relación do axente da microfinanceira que lle confían as persoas que configuran a contorna, que nun sistemas de garantías.

Os microcréditos, que son a expresión máis xenuína das microfinanzas², aínda que non a única, en xeral funcionan sobre a base de pequenas cantidades cedidas en empréstito aos necesitados que teñen unha idea de negocio, aínda cando poden tamén ser destinados a melloras nas explotacións agrícolas, se as teñen, aos estudos dos fillos ou a calquera outra necesidade perentoria. Con todo, empregar o crédito na creación dunha microempresa é, así mesmo, a razón máis frecuente e a que máis se adapta á natureza inicial das microfinanzas.

Os servizos das microfinanzas funcionan de xeito parecido aos tradicionais que ofrece toda a banca do mundo, dende o crédito, como xa dixemos, ata o aforro, porque os máis pobres resultaron ser excelentes aforradores e o que parece un paradoxo non o é xa que o aforro é unha necesidade que lle permite ao pobre manexarse con certa tranquilidade con respecto ao seu futuro. A microfinanza pois, proporciona financiamento aos pobres á vez que lles proporciona os servizos bancarios que necesitan e, se ata a aparición da microfinanza non accederan, polo xeral, a eles era sinxelamente porque ou non os coñecían ou non existían na súa contorna. En definitiva que non estaban bancarizados porque o sistema os excluía. Dende logo, todo iso parte da perspectiva da microempresa e de acordo coas necesidades das pequenas economías.

A relación entre o pobre convertido en cliente e a microfinanceira na maior parte dos casos non é ocasional, non se limita a un crédito e a seu devolución senón que, polo xeral, establécese unha relación de negocio crecente entre as dúas partes. Ao primeiro crédito, dunha cantidade moi baixa, adoitan seguir outros de maior

1 Virreira defíneas do siguinte xeito: "Microfinanzas, por tanto, refírense aos servizos financeiros nunha escala reducida -sobre todo crédito e aforros- proporcionados á xente que cultiva, pesca ou cría animais; que opera empresas pequenas ou microempresas onde se producen, se reciclan, reparan ou venden mercadorías; que proporcionan servizos; que gañan un ingreso por alugueres de pequenas parcelas de terra, vehículos, animais de traballo ou maquinaria e ferramentas; e a outros individuos e grupos no ámbito local de países en vías de desenvolvemento, tanto en áreas rurais como urbanas. Moitos deles teñen múltiples fontes de ingreso" (Virreira Centellas, 2010). É importante esta definición porque formulouse nunha data moi posterior á aparición das microfinanzas, cando xa se asentaran e ocupaban un sector importante na estrutura financeira mundial.

2 "As microfinanzas nacen, pois, como unha resposta á ausencia de servizos financeiros formais para amplas capas das poboacións de países en desenvolvemento e ao abuso por parte dos usureiros debido ao difícil acceso ao crédito nos devanditos países. A metodoloxía microfinanceira substitúe o sistema de garantías baseado no aval por un sistema baseado, por exemplo, na promesa por parte do prestamista da concesión de maiores créditos no caso de que o primeiro crédito sexa reembolsado ou na presión social exercida polos membros do grupo de prestatarios cando o empréstito é solidario" (Bicciato et al., 2002). 
envergadura, así como a utilización de todos os servizos bancarios ofrecidos, dende transferencias e seguros, asesoramento na microempresa ou tarxetas de crédito. Estes novos créditos serven para ampliar o negocio ou comprar un local para o mesmo, en definitiva para ampliar as posibilidades de gañar diñeiro e saír do círculo da pobreza.

Unha das características das microfinanzas é a súa incidencia na equidade de xénero, un fenómeno que se produciu en todas as sociedades nas que se instalaron. O feito incontestable é que reforzan o empoderamento da muller, que é a que, na maioría dos casos, faise cargo do crédito, inicia a empresa, traballa nela, coida 0 proceso do negocio, paga os reintegros e os intereses e coopera fundamentalmente co benestar e a calidade de vida da familia. Tanto é así que as mulleres significan máis do $90 \%$ dos clientes do Banco Grameen ${ }^{3}$.

A incidencia das microfinanzas, especialmente os microcréditos, na economía dunha área, neste caso Bangladés, é evidente xa que mentres só o $4 \%$ dos pobres deste país que non obtiveron microcréditos saíron da pobreza, fixérono o 48\% dos que solicitaron e obtiveron microcréditos.

\section{2.- TIPOLOXÍA DO CLIENTE.}

Establecer unha tipoloxía do cliente das microfinanzas presenta grandes dificultades xa que na práctica existen tantos tipos como usuarios. En realidade a case única característica que comparten é a pobreza, e aínda así o concepto de pobreza é diferente e conxuntural segundo o país. Unha primeira análise levaríanos a establecer que tanto os homes como as mulleres son clientes das microfinanzas, pero as mulleres son o grupo maioritario, utilizan mellor o microcrédito, pagan mellor e máis ao día os intereses e devolven antes o capital cós homes. A clasificación máis usada baséase, precisamente, no nivel de pobreza:

1.- Indixentes.

2.- Extremadamente pobres.

3.- Moderadamente pobres.

4.- Vulnerables pero non pobres.

En todo caso, o cliente tipo das microfinanzas é unha muller do primeiro ou segundo grupo, con fillos, que ten ao seu cargo a familia. E se ben é certo que as mulleres resultaron ser as grandes usuarias das microfinanzas, cunha óptima utilización para manter e elevar o nivel de vida da familia e a súa seguridade, ademais de destacar como excelentes pagadoras dos compromisos adquiridos, as microfinanzas, pola súa banda, proporcionaron ás mulleres a oportunidade de emanciparse e contribuíron a un maior empoderamento das mesmas. (Cheston e Kuhn, 2006).

\section{3.- TIPOLOXÍA DOS SERVIZOS.}

As microfinanceiras, como xa dixemos, proporcionan outros servizos ademais dos coñecidos microcréditos. De feito trátase de todos os servizos básicos que ofrece a banca aos seus clientes, entre os cales os máis interesantes para os clientes deste tipo de institucións son os servizos de aforro e seguros.

Dende logo, os microcréditos non son só a estrela das microfinanzas senón a razón das mesmas e, directa ou indirectamente, ata este momento estivémonos referindo

3 O Banco Grameen fundouse por Muhammad Yunus, Premio Nobel da Paz de 2006 polos seus traballos financeiros para a promoción dos pobres. $\mathrm{O}$ Banco fundouse e ten maior incidencia en Bangladés. 
a eles e por iso obviamos explicar máis o seu funcionamento e incidencia e centrámonos nos dous servizos que os seguen en interese para os clientes das microfinanzas.

O Aforro cumpre dúas funcións: por unha banda garantir unha reserva ao cliente que lle permite cubrir unha necesidade conxuntural e por outra capitalizar á microfinanceira. Nunha primeira etapa, as institucións microfinanceiras financiáronse na súa maior parte con achegas estatais. Certo é que dende hai uns anos entrou neste sector o capital privado como orixe do financiamento e grandes institucións bancarias fixeron acto de presenza no negocio. No noso país dous exemplos son o Banco de Santander e A Caixa de Barcelona que están realizando un importante negocio tanto en España como no resto de Europa.

A capacidade de aforro é moi elástica e en maior ou menor medida está presente en todos os niveis de pobreza, incluída a indixencia, iso si, con diferentes cantidades. $\mathrm{E}$ os moi pobres ou pobres coñecen os beneficios do aforro aínda cando sempre tiveron unha marcada desconfianza das institucións financeiras, polo que é necesario que a microfinanceira ofreza unhas condicións aceptables para os pobres, que adoitan ser:

- Proxectar confianza.

- Ofrecer acceso rápido aos aforros, mellor unha liquidez inmediata. Non son moi apreciadas as ventaxes das imposicións a longo prazo.

-- Custo baixo de depósitos e reintegros, mellor aínda se non teñen cargos.

- É máis importante para os depositarios o servizo cá taxa de interese que reciben. $\mathrm{O}$ cal implica que o aforro dos pobres non é un modo de facer rendible o diñeiro, senón un método para se asegurar contra unha desgraza imprevista. (Vonderlack e Schreiner, 2001).

Táboa 4a.- Custos de xestión dos microcréditos segundo Felder-Kuzu, (2010, p. 44).

\begin{tabular}{lcc}
\hline $\begin{array}{c}\text { Comparación de costes entre un préstamo de } \\
\text { y un préstamo de } 1.000 \text { dólares }\end{array}$ \\
\hline $\begin{array}{c}\text { Préstamo } \\
\text { de } 100 \\
\text { dólares }\end{array}$ & $\begin{array}{c}\text { Préstamo } \\
\text { de } 1.000 \\
\text { dólares }\end{array}$ \\
\hline Costes de tramitación (20 dólares) & 20 & 20 \\
Costes de financiación ( $8 \%)$ & 8 & 80 \\
Provisión por impagos (2\%) & 2 & 20 \\
Costes totales en dólares & 30 & 120 \\
Costes totales en forma \\
de porcentaje del préstamo
\end{tabular}

Esta táboa amosa unha comparación dos custos dos empréstitos por cantidade. A menor cantidade do empréstito maior custo ${ }^{4}$.

4 “O tamaño do crédito ten un impacto máis decisivo na eficiencia cá escala, particularmente se os créditos promedio son menores de US $\$ 300$. En operacións bancarias en cidades pequenas, 
Para as microfinanceiras, o aforro converteuse no segundo factor de financiamento e nalgunhas institucións pasou a ser o primeiro, aínda que o sector non dubida que no futuro será o máis destacado. Con todo, a microfinanceira debe enfrontarse con dous problemas con respecto ao aforro, unha de tipo legal e outra de custos. En primeiro lugar, os problemas legais veñen dunha falta de lexislación sobre 0 subsector das microfinanceiras que deixan no ar a regulación do aforro tanto dende o marco de garantías como dende a súa xestión. Esta problemática afecta máis aos países occidentais con forte medidas reguladoras do sector bancario que entre os países do terceiro mundo onde as normativas son, alomenos, máis suaves.

En segundo lugar, os custos de control dos aforros son máis caros que na banca tradicional, dado que presentan un maior número de contas con moito menos capital aforrado, o que provoca unha sobredimensión dos trámites administrativos que se converten en custos, aínda cando estas situacións son unha constante no mundo das microfinanzas, tanto no aforro, como no microcrédito.

Unha relación superficial dos servizos microfinaceiros sería: microaforro; microseguros de vida; microseguros de saúde; microseguros de accidentes ou calamidades naturais; envío de remesas (especialmente dos emigrantes); microleasing; microrenting; instrumentos de pago, fondos mutuos de garantía; fondos de pensións e asesoramento.

\section{4.- INSTITUCIÓNS MICROFINANCEIRAS: ENTIDADESDE SEGUNDO PISO}

Tanto as institucións microfinanceiras como os clientes das mesmas teñen unha difícil clasificación xa que son de moitos tipos tanto organicamente como en función da contorna á que se dirixen. Os tipos van desde as ONGs, que foron as primeiras que deron microcréditos, aínda que non moi diferenciados ao principio das microsubvencións ou axudas sen obriga de devolución, ata bancos tradicionais, como indicamos anteriormente, que se introduciron no subsector por entender, e con razón, que era un campo no que se podían facer rendibles os investimentos. Pero non son os únicos tipos: cooperativas de aforro, asociacións comunais, institucións privadas ou públicas de cooperación en distintos sectores e ata oficinas postais entraron no subsector das microfinanzas.

Nembargantes, unha das clasificacións que subsistiu ao longo dos anos está baseada na funcionalidade das institucións microfinanceiras e as estruturan en institucións de Segundo Piso e institucións de Primeiro Piso. As primeiras son as fontes dos fondos das segundas, ou sexa son as súas provedoras de financiamento. As de Primeiro Piso son as que tratan directamente co público, cos clientes e dalles microcréditos e todos os servizos que precisan para as súas microempresas. Isto non implica necesariamente que os límites dunhas e outras estean claramente definidos. Institucións de Segundo Piso poden, e nos países occidentais adoitan, implicarse tamén nas operacións de Primeiro Piso, directamente ou a través dalgunha empresa financeira subsidiaria.

4.1.- Entidades de Segundo Piso.

Como dixemos son aquelas que proporcionan o financiamento ás de Primeiro Piso. A súa aparición débese ás dificultades con que se atopaban os grandes organismos internacionais, incluídos os Estados, para chegar ás institucións que directamente trataban cos clientes de microcréditos. Os organismos internacionais de

por exemplo, onde o promedio do tamaño dos créditos a miúdo chega a cifras equivalentes a US \$130 ou menos, os gastos operativos adoitan ser maiores ao $40 \%$ da carteira bruta promedia." (Banco Interamericano de desenvolvemento, 2003) 
cooperación atopábanse cunha chea de ONGs e pequenas microfinanceiras, repartidas en zonas de difícil acceso de países do terceiro mundo, e os orzamentos que tiñan estes organismos para determinadas axudas non atopaban canles fáceis para instituírse. Hai que ter en conta que as entidades microfinanceiras no terceiro mundo son moitas e pequenas e chegar a todas ou ás máis interesantes pola súa especialidade ou área á que se dirixían era, canto menos, difícil.

Neste contexto suscítase o problema da sustentabilidade das microfinanceiras. Enténdese que unha microfinanceira é sustentable se cobra cos ingresos os custos operativos, custos de fondos, de inflación e as provisións para errados. Neste aspecto as microfinanceiras clasifícanse en catro niveis:

Primeiro nivel: a microfinanceira depende por completo dos fondos subsidiados. Son entidades que prestan por debaixo dos intereses do mercado e non cobren os seus custos operativos.

Segundo nivel: operan só en parte con fondos subsidiados as súas taxas de interese están máis preto das do mercado. Cobren unha parte dos custos operativos pero non todos, o que lles obriga a depender de subvencións e donacións como no primeiro nivel.

Terceiro nivel: establecen taxas de mercado nas súas operacións o que lles permite cubrir custos operativos. Tamén teñen unha estrutura máis eficiente e menos custosa có primeiro caso. Hai unha maior profesionalización e máis interese no negocio como empresa.

Cuarto nivel: a entidade finánciase totalmente sobre a base do seu capital propio, dos fondos que conseguen do mercado de capitais e dos depósitos dos clientes, como calquera outra entidade do sector.

Subsiste un problema dende o principio da existencia das entidades de Segundo Piso, que mesmo xurdía antes da súa institución. Estes fondos, e ata as propias entidades de Segundo Piso, están en moitos casos baixo o control de gobernos ou políticos que inflúen para que os fondos vaian a unha ou outra institución de Primeiro Piso ou cara a un fin que lles interese politicamente.

En todo caso aínda que as institucións de Segundo Piso pódense cuestionar, entendemos que na actualidade e dada a estrutura do subsector son úteis e necesarias, aínda cando o seu futuro é discutible non pola súa función política ou polos seus custos, senón porque as institucións de Primeiro Piso cada vez tenden máis a autofinanciarse e están moi preto de conseguilo plenamente.

4.2.- Entidades de Primeiro Piso.

Trátase, como dixemos, das entidades que tratan directamente cos clientes das microfinanzas e encárganse de prestar servizos financeiros aos máis pobres. Aparecen na década dos cincuenta respondendo aos primeiros movementos de cooperación que se materializan a través de ONGs e institucións gobernamentais de cooperación e axuda. Nunha primeira etapa inciden de xeito prioritario no sector rural; os primeiros programas tratan de elevar o nivel de vida dos agricultores ao proporcionarlles maquinaria, información na súa especialidade e financiar os investimentos necesarios para facer rendibles os seus predios.

4.3.- ONGs

As ONGs foron non só as introdutoras das microfinanzas na maior parte das contornas de pobreza onde se desenvolveron, senón tamén das innovacións que configuraron ao longo dos últimos cincuenta anos o subsector financeiro que estamos tratando.

Dificilmente pódese atopar un país subdesenvolvido no cal as ONGs non instituíran programas de microcréditos. Por outra banda tamén son estas organizacións as que 
máis elixen os gobernos e as organizacións internacionais para canalizar a través delas as subvencións e axudas. As ONGs partiron, nas décadas dos oitenta e noventa, con vantaxe sobre outro tipo de organizacións xa que actuaban sobre o terreo e coñecían as características da contorna social. A principios da segunda das décadas citadas as ONGs crearon o que se veu chamar "tecnoloxías do microcrédito" que non son máis que os elementos necesarios para que o subsector das microfinanzas pasaran de subvencionar a financiar. Estas novas estruturas cambiaron o funcionamento das microfinanzas e permitiu que estas puidesen establecer un negocio financeiro con posibilidades de se perpetuar ao obter beneficios e acadar a autofinanciación (Marulanda e Otero, 2005).

As ONGs utilizaron tres modelos para converterse en entidades financeiras baixo regulación: No primeiro caso pasaron de ONG a entidade financeira regulada, de maneira que a ONG cesa nas súas actividades, desaparece como tal e aparece a entidade financeira. No segundo caso, a ONG crea a entidade financeira regulada pero mantén tamén as súas actividades como ONG. Subsisten, pois, dúas entidades que actúan complementariamente; a microfinanceira ofrece os servizos financeiros aos clientes e a ONG as axudas e apoios que estes necesitan. Este segundo tipo é o máis usado. O terceiro caso é cando a ONG é a orixe dun grupo de empresas, cada unha das cales se especializa nun tipo de servizos: microseguro, microcrédito, leasing, servizos de apoio, servizos formativos, etc. As ONG que optan por este terceiro tipo adoitan ser as que teñen maior capacidade financeira e humana, xa que é unha opción moi completa pero implica unha gran organización.

A reconversión de ONGs en empresas de microfinanzas significou unha estratexia exitosa xa que o traballo de asistencia aos máis necesitados, que era a esencia das devanditas organizacións, mantense na nova formulación e, coa oferta de servizos microfinanceiros, non só chegan aos máis pobres senón que conseguen un sistema de financiamento, os beneficios e o aforro, que lles permiten autofinanciarse, que é algo así como o soño de toda ONG.

Moitas destas organizacións seguen, como xa dixemos, co obxectivo principal asistencial e de desenvolvemento social aínda cando non sempre ambas actividades, microfinanzas e desenvolvemento social, pódense complementar con éxito dentro da mesma ONG. Isto non quere dicir que no futuro, as ONGs, non logren implementar outras innovacións e desenvolver o seu modelo de axuda con plena eficacia e éxito.

4.4.- Cooperativas de Aforro e Crédito.

Aínda que non se pode dicir que as cooperativas de Aforro e Crédito sexan o mesmo que as microfinancireras, é certo que dende a segunda metade do século XIX, veñen intermediando na afiliación de millóns de cooperativistas que se atopan nos limiares da pobreza e necesitan destas organizacións para obter crédito e financiamento.

Este tipo de cooperativas ás que nos estamos referindo cobre as necesidades de máis de 200 millóns de persoas no mundo e están estendidas en máis de 100 países, segundo datos do Consello Mundial de Cooperativas de Aforro e Crédito (WOCCU). Ofrecen, non só créditos senón tamén outros servizos financeiros moi parecidos aos que se poden conseguir nunha microfinanceira.

Este tipo de cooperativas financeiras son propiedade dos socios, financian as súas carteiras de créditos, recaudan e fan rendibles os seus aforros, e traballan principalmente con capital propio que devén dos devanditos aforros e dos beneficios. 
Táboa 5a-. Número de países e socios membros de cooperativas

\begin{tabular}{|llll|}
\hline Ano & Países & CAC & Socios \\
2012 & 101 & 55,952 & $200,243,841$ \\
2011 & 100 & 51,013 & $196,498,738$ \\
2010 & 100 & 52,945 & $187,986,967$ \\
2009 & 97 & 49,330 & $183,916,050$ \\
2008 & 97 & 53,689 & $185,800,237$ \\
2007 & 96 & 49,134 & $177,383,728$ \\
2006 & 96 & 46,367 & $172,007,510$ \\
2005 & 92 & 42,705 & $157,103,072$ \\
2004 & 82 & 41,042 & $128,338,297$ \\
\hline
\end{tabular}

Fonte: Informe do Consello Mundial de Cooperativas de Aforro e Crédito.

Táboa 6⿳a - Estatísticas financeiras sobre as Cooperativas de Aforro e Crédito.

\begin{tabular}{|lrrrr|}
\hline Ano & Aforros (USD) & Empréstitos (USD) & Reservas (USD) & Activos (USD) \\
2012 & $\$ 1,293,256,192,197$ & $\$ 1,083,818,986,318$ & $\$ 161,810,294,796$ & $\$ 1,693,949,441,327$ \\
2011 & $\$ 1,221,635,067,920$ & $\$ 1,016,243,687,593$ & $\$ 141,314,921,922$ & $\$ 1,563,529,230,923$ \\
2010 & $\$ 1,229,389,373,992$ & $\$ 960,089,324,653$ & $\$ 131,659,476,972$ & $\$ 1,459,605,561,772$ \\
2009 & $\$ 1,145,851,168,440$ & $\$ 911,752,609,007$ & $\$ 119,738,181,488$ & $\$ 1,352,608,897,477$ \\
2008 & $\$ 995,741,235,545$ & $\$ 847,058,749,226$ & $\$ 115,316,544,867$ & $\$ 1,193,811,863,722$ \\
2007 & $\$ 987,861,248,618$ & $\$ 847,896,069,374$ & $\$ 115,358,461,836$ & $\$ 1,181,465,915,014$ \\
2006 & $\$ 904,120,858,300$ & $\$ 758,208,659,672$ & $\$ 106,825,743,418$ & $\$ 1,092,135,905,636$ \\
2005 & $\$ 763,819,930,158$ & $\$ 612,201,609,601$ & $\$ 91,557,493,495$ & $\$ 894,454,835,782$ \\
2004 & $\$ 707,438,184,755$ & $\$ 531,418,500,904$ & $\$ 82,926,748,099$ & $\$ 824,653,392,302$ \\
\hline
\end{tabular}

Fonte: Informe do Consello Mundial de Cooperativas de Aforro e Crédito.

A WOCCU define ás cooperativas de aforro e crédito como institucións de tipo financeiro sen ánimo de lucro que, como dixemos, son propiedade dos socios que usan os seus servizos. Ditas cooperativas facilitan crédito e xestionan os aforros dos seus socios, que poden gozar de todos estes servizos a un custo baixo ${ }^{5}$.

A característica distintiva con outras organizacións financeiras, incluídas as microfinanzas, é que non lles move o interese polo lucro, dado que os propietarios son os socios e o obxectivo é proporcionarlles o mellor servizo ao mínimo custo. Calquera beneficio é reintegrado aos socios en forma dunha máis alta taxa de interese sobre os seus aforros e un menor custo sobre os créditos. Por outra banda, están máis preto das microfinanceiras que da banca comercial xa que as súas contas 
de aforro ou a cantidade dos seus créditos son pequenas, pero teñen uns custos operativos máis baixos que as microfinanceiras, coas que compiten en determinados treitos e áreas.

Os asociados, como na maioría das cooperativas, teñen un voto por socio nas Asembleas Xerais, sen ter en conta os depósitos que teñan na Cooperativa, o que permite unha maior liberdade de toma de decisións e unha maior implicación na organización. Deben enfrontarse cunha problemática frecuente nestas institucións: a cooperativa que ten por obxectivo, como se dixo, a autofinanciación e evitar recorrer ao capital exterior polos custos que representa, debe instituír uns sistemas de supervisión e control que permita un cálculo real e continuo dos custos e a distribución dos excedentes, xa sexan en intereses sobre aforros ou créditos.

Tamén están suxeitas ao control das autoridades estatais correspondentes especialmente no relativo aos investimentos que se realizan destes aforros para que sexan rendibles. Se os aforros se destinan a ampliar a carteira de créditos, realmente non resultan moi rendibles pola propia natureza das cooperativas, pero os investimentos fóra delas teñen, en calquera caso, riscos que a cooperativa non se pode permitir. A perda do diñeiro dos socios depositados na entidade adoita significar o fin da traxectoria da mesma.

As cooperativas de Aforro e Crédito, aínda que traballen en escenarios parecidos aos das microfinanceiras, e ata utilicen procedementos parecidos, pero non totalmente iguais, son cooperativas non microfinanceiras.

\section{5.- BANCA COMERCIAL.}

Referímonos, evidentemente á banca comercial que se adica ás microfinanzas. Excepto nalgún caso concreto, como o Banco Grameen fundado especialmente para dar microcréditos aos máis pobres, a banca comercial que se adica ás microfinanzas son divisións dos bancos comerciais xerais ou organizacións creadas por eles co financiamento necesario e adicadas ás microfinanzas como unha especialidade máis. Este é o caso dos bancos comerciais que desenvolveron accións neste subsector en Europa.

Un dos primeiros desenvolvementos deste tipo de banca comercial adicada ás microfinanzas foi na América Latina e no Caribe, onde as microfinanzas están moi enraízadas no sector agrícola e as cantidades dos microcréditos son máis altas que no sueste asiático. Este tipo de bancos non adoita traballar co primeiro e máis tráxico nivel de pobreza, os indixentes, senón co terceiro e cuarto niveis, que lles ofrecen maiores garantías por unha banda e por outra, ao ser cantidades máis altas, menores custos de xestión (Westley, 2007).

Existen moitos factores que impulsaron á banca comercial a entrar no subsector das microfinanzas. A primeira e, ao noso xuízo a máis importante, son os elevados rendementos do capital xa que, como indicamos, os intereses que se manexan nos microcréditos son altos, tanto é así que segundo MicroRate os rendementos sobre activos en Latinoamérica chegaron a taxas do 17,7\%. Tamén influíu unha forte demanda que non podían cubrir as entidades microfinanceiras que ocupaban o mercado; os escasos índices de morosidade e a necesaria diversificación de carteiras con que se atopaba a banca comercial e, dende logo, unha política de imaxe fronte aos seus clientes tradicionais.

Tampouco hai que esquecer que os primeiros pasos da banca comercial dentro do mundo das microfinanzas deron lugar a entidades de Segundo Piso, encargadas de distribuír os fondos subvencionados ou foron depositarios e xestores dos mesmos. A xestión operativa das microfinanzas non é a mesma cá banca comercial, polo que 
as estruturas destas divisións ou departamentos, debe axustarse ás características das primeiras (Wenner, e Campos, 2000). Nembargantes, non suscita tantos problemas a conversión dunha parte dun banco comercial nunha microfinanceira, se se considera que a xestión do día a día dun banco que teña sucursais por exemplo en pobos agrícolas, non varía moito da das microfinanceiras.

O problema do contacto directo cos clientes e a súa contorna para realizar avaliacións que lles permitan coñecer as garantías de devolución, non existe para un bancario afeito ao trato cos clientes dunha vila. É máis, nas mesmas vilas nas que se atopan as sucursais dos bancos comerciais e nos mesmos locais, pódense realizar as operacións de microfinanzas, polo que o investimento do banco comercial é mínima.

É certo que para que as microfinanzas sexan realmente rendibles hai que minimizar os gastos operativos que son altos, pero coa axuda das novas tecnoloxías, que os bancos comerciais incorporaron xa hai tempo, é perfectamente posible.

Para rematar tamén é necesario que o banco, como a microfinanceira, estea asentado, sexa coñecido entre os posibles clientes e que lle teñan a suficiente confianza como para confiarlle os seus aforros, o cal é perfectamente compatible cun banco comercial xa asentado na zona.

6.- RATIOS FINANCEIRAS MÁIS EMPREGADAS NO SECTOR DAS MICROFINANZAS.

As ratios financeiras máis empregadas nas microfinanzas estrutúranse en catro agrupacións:

Sustentabilidade/ Rendibilidad.:

Rendimento sobre o capital:

Mide a capacidad para aumentar os beneficios da empresa e o aumento do patrimonio por medio dos rendimentos da súa operativa.

Rendimento sobre activos:

Mide o uso dos activos segundo o rendimento das operacións. Se se inclúen só os factores operativos e se exclúen os non operativos, é un indicador das posibilidades futuras da empresa microfinanceira.

Suficiencia Operativa:

É a relación entre os custos e os rendimentos operativos.

Marxe de beneficio:

Porcentaxe de ingresos operativos despois dos gastos financeiros, operativos e provisións.

Xestión de Activo/ sPasivos

Rendimento sobre carteira bruta:

Mide a capacidad da carteira bruta de xerar ingresos.

Gastos de financiación:

Trátase de obter o custo combinado do financiamento da carteira de microcréditos.

Custo dos Fondos:

Trátase do custo combinado do total das fontes de financiación da microfinanceira.

Calidade da carteira.

Carteira en risco:

É a medida da calidade da carteira, neste caso de microcréditos, e consiste na porcentaxe da morosidade.

Carteira cancelada:

Son os microcréditos declarados impagados.

Cobertura de risco: 
Unha parte, ou toda, a carteira de risco cuberta polas previsións. Implica a capacidade da entidade para se enfrontar aos impagos.

Eficiencia/ Produtividade.

Produtividade do oficial de crédito:

Número de clientes promedio que pode cubrir un xestor ao mesmo tempo.

Valor medio do microcrédito:

Promedio dos microcréditos concedidos.

Ratio de Gastos Operativos:

É medir a eficacia das microfinanceiras

Custo por cliente:

É o custo medio dun cliente activo. (AA.VV., 2003).

\section{7.- CONCLUSIÓNS}

O éxito das microfinanzas, considerando os seus obxectivos básicos e o desenvolvemento do subsector foi espectacular a partir das dúas últimas décadas do século XX e os primeiros anos do século XXI. Os seus obxectivos primeiros foron proporcionar unha esperanza aos sectores máis pobres dos países máis pobres e isto sen dúbida foi acadado. Tamén había que conseguir un aumento do nivel de vida desas clases sociais empobrecidas e marxinais na sociedade, aínda cando por número eran as que reunían o maior volume de persoas. E conseguiron elevar o nivel de vida de importantes grupos de familias cuxo futuro, antes das microfinanzas, era moi problemático ou simplemente non existía.

Os diversos servizos que ofrecen as microfinanzas, estruturados ao redor do produto estrela, o microcrédito, contribuíron a crear un sistema microfinanceiro que conseguiu incidir nos Produtos Interiores Brutos de moitos países do terceiro mundo. Pero, sobre todo, crearon unha cultura financeira entre os pobres, dende 0 primeiro e máis mísero nivel ao da relativa pobreza, que lles permite non só xestionar os seus microcréditos senón aforrar en previsión de futuras necesidades e introduciuna en modernas formas de negocios e tecnoloxías achegadas. En definitiva realizou un traballo considerable na promoción económica, educativa e social dos máis desposuídos.

As microfinanzas, xa na segunda década do século XXI, enfróntanse con problemas derivados, en boa parte, deste éxito. O primeiro deles é o financiamento e o segundo o desembarco dos bancos comerciais no subsector. O financiamento foi, en parte, resolto polo aforro dos propios clientes e, tamén, pola entrada de capital atraído polas posibilidades dun negocio rendible. Os bancos comerciais entraron no negocio atraídos, así mesmo, polos seus rendementos. O problema nos dous casos, a entrada de capital nas microfinanceiras e a entrada dos bancos comerciais no negocio, suscitan unha dúbida: cal será a súa posición fronte aos obxectivos tradicionais das microfinanzas?

As microfinanzas nacen con vocación de axuda aos máis pobres. Os capitais e os bancos comerciais, que son a máis xenuína expresión daqueles, teñen como obxectivo principal os beneficios. É posible un sincretismo entre estes dous obxectivos? O problema non está tanto nos clientes dos microcréditos que conseguiron saír da pobreza e se integraron nunha clase social máis elevada e económicamente máis forte, senón nos miles de millóns de pobres que aínda seguen na pobreza extrema ou case nela, aos que non lles queda máis esperanza que a axuda e a cooperación para saír da pobreza.

Os próximos anos darannos unha resposta que de momento non parece moi alentadora. 
BIBLIOGRAFÍA.

AA.VV. (2003): "Definitions of Selected Financial Terms, Ratios and Adjustments for Microfinance", Washington, CGAP, Microfinance Consensus Guidelines.

BANCO INTERAMERICANO DE DESARROLLO. (2003): Indicadores de desempeño para instituciones microfinancieras. Guía técnica. Washington D. C.: Banco Interamericano de Desarrollo.

BICCIATO, F.; FOSCHI, L.; BOTTARO, E.; GANAPINI, F. I. (2002): Microfinanzas en países pequeños de América Latina: Bolivia, Ecuador y El Salvador, Serie Desarrollo Productivo no 121, División de Desarrollo Productivo y Empresarial. Santiago de Chile: CEPAL, febrero.

CHESTON, S.; LISA KUHN, L. (2006): Empowering Women through Microfinance. Nueva York: UNIFEM.

GUTIÉRREZ GOIRIA, J.; UNCETA SATRUSTEGI, K. (2011): Instrumentos y actores de la actuación española en microfinanzas en el exterior: ¿cómo se complementan? Valladolid: Cumbre Mundial del Microcrédito.

FELDER-KUZU, N. (2010): Microfranquicias. Casos Prácticos. Más allá de los microcréditos. Madrid: Ariel.

GARCÍA FERNÁNDEZ-MURO, C.; OLIVÉ ALDASORO, I. (2003): Alcance versus desempeño financiero en los programas de microfinanzas: Apuntes Teóricos y Algunos ejemplos. Madrid: Revista de Economía Mundial, núm. 9, 129-152

LEDGERWOOD, J. (1999): Manual de Microfinanzas. Una perspectiva institucional y financiera. Washington: Banco Mundial.

MARULANDA, B.; OTERO, M. (2005): Perfil de las microfinanzas en Latinoamérica en 10 años: Visión y Características. Boston: ACCION Internacional, Pág. 4.

VIRREIRA CENTELLAS, R. (2010): Introducción a las Microfinanzas. Buenos Aires: AFIN, Centro Internacional de apoyo a las innovaciones financieras

VONDERLACK, R. M.; SCHREINER, M. (2001): Mujeres, Microfinanzas y Ahorro: Lecciones y Propuestas. Washington: Center for Social Development.

WENNER, M. D.; CAMPOS, S. (2000): Lecciones en la penetración de la banca comercial en microfinanzas. Washington: Banco Interamericano de Desarrollo

WESTLEY, G. D. (2007): Bancos comerciales en microfinanzas: Mejores prácticas y directrices para el diseño, seguimiento y evaluación de proyectos. Washington: Banco Interamericano de Desarrollo.

YUNUS, M (2010): El banquero de los pobres. Los microcréditos y la batalla contra la pobreza en el mundo. Barcelona: Paidos.

Anexo on line at http:/ / www.usc.es/ revistas/ index.php/ rge 
Tipos de organizacións de microfinanzas. Esta clasificación é de Tabonga e Lucano e mostra que xa en 1998 foron estruturadas as institucións de microfinanzas e desenvolvido practicamente todos os recursos ofrecidos hoxe.

Táboa 1a.- Tipos de microfinancieiras (clasificación de Tabonga e Lucano)

\begin{tabular}{|c|c|c|c|c|}
\hline & $\begin{array}{l}\text { Instituciones } \\
\text { financieras } \\
\text { multipropósito }\end{array}$ & $\begin{array}{l}\text { Instituciones } \\
\text { financieras } \\
\text { especializadas }\end{array}$ & $\begin{array}{c}\text { Organizaciones } \\
\text { no gubernamentales } \\
\text { especializadas }\end{array}$ & $\begin{array}{c}\text { Organizaciones no } \\
\text { gubernamentales } \\
\text { en general }\end{array}$ \\
\hline $\begin{array}{l}\text { Estrategia/Propósito } \\
\text { de las actividades }\end{array}$ & $\begin{array}{l}\text { Nuevo mercado; } \\
\text { imagen; filantropía }\end{array}$ & $\begin{array}{l}\text { Impacto social; } \\
\text { crecimiento; beneficios }\end{array}$ & $\begin{array}{l}\text { Impacto social; } \\
\text { sostenibilidad; beneficios }\end{array}$ & $\begin{array}{l}\text { Impacto social; } \\
\text { sostenibilidad; beneficios }\end{array}$ \\
\hline Forma legal & $\begin{array}{l}\text { Bancos, compañías } \\
\text { financieras } \\
\text { y cooperativas }\end{array}$ & $\begin{array}{l}\text { Bancos y compañías } \\
\text { financieras }\end{array}$ & $\begin{array}{l}\text { Fundaciones; } \\
\text { asociaciones }\end{array}$ & $\begin{array}{l}\text { Fundaciones; } \\
\text { asociaciones }\end{array}$ \\
\hline Clientes & $\begin{array}{l}\text { Varios; pequeñas } \\
\text { empresas y } \\
\text { microempresas con } \\
\text { participación } \\
\text { en el portafolio }\end{array}$ & $\begin{array}{l}\text { Pequeñas empresas } \\
\text { y microempresas }\end{array}$ & Microempresas & Microempresas \\
\hline Servicios & $\begin{array}{l}\text { Varios segmentos } \\
\text { focalizados } \\
\text { del mercado; } \\
\text { crédito individual; } \\
\text { ahorros }\end{array}$ & $\begin{array}{l}\text { Crédito individual; } \\
\text { crédito a grupos; } \\
\text { oferta limitada } \\
\text { de leasing, } \\
\text { factoring etc.; } \\
\text { ahorros }\end{array}$ & $\begin{array}{l}\text { Crédito individual; } \\
\text { préstamos solidarios; } \\
\text { banca municipal }\end{array}$ & $\begin{array}{l}\text { Crédito individual; } \\
\text { préstamos solidarios; } \\
\text { banca municipal }\end{array}$ \\
\hline $\begin{array}{l}\text { Fuentes } \\
\text { de financiamiento }\end{array}$ & $\begin{array}{l}\text { Ahorros; acciones; } \\
\text { bonos; préstamos } \\
\text { comerciales }\end{array}$ & $\begin{array}{l}\text { Ahorros; acciones; } \\
\text { préstamos } \\
\text { comerciales }\end{array}$ & $\begin{array}{l}\text { Préstamos } \\
\text { comerciales y } \\
\text { préstamos blandos; } \\
\text { garantías; donaciones }\end{array}$ & $\begin{array}{l}\text { Donaciones; } \\
\text { créditos blandos; } \\
\text { garantías }\end{array}$ \\
\hline Ejemplos & $\begin{array}{l}\text { Banco Solidario } \\
\text { (Ecuador); Financiera } \\
\text { Familiar (Paraguay); } \\
\text { Coop. Fucac } \\
\text { (Uruguay); } \\
\text { MultiCredit Bank } \\
\text { (Panamá) }\end{array}$ & $\begin{array}{l}\text { Fin. Calpia (El Salvador); } \\
\text { BancoSol (Bolivia); } \\
\text { Caja Los Andes (Bolivia); } \\
\text { FinSol (Honduras); } \\
\text { FinAmerica (Colombia); } \\
\text { Edyficar (Perú); } \\
\text { Banco Ademi } \\
\text { (R. Dominicana) }\end{array}$ & $\begin{array}{l}\text { WWB (Colombia); FED } \\
\text { (Ecuador); Acodep } \\
\text { (Nicaragua); ADRI } \\
\text { (Costa Rica) }\end{array}$ & $\begin{array}{l}\text { Fundasol (Uruguay); } \\
\text { Fundación Carvajal } \\
\text { (Colombia); } \\
\text { Fundación Cesap } \\
\text { (Venezuela) }\end{array}$ \\
\hline
\end{tabular}

Fonte: Lucano e Tabonga, (1998) 
Pola sua parte, Ledgerwood (1999, p. 109) as clasifica da seguinte maneira:

Taboa 2a -- Tipos de institucións microfinancieiras, Ledgerwood, 1999.

\begin{tabular}{|c|c|}
\hline Institucións formais: & $\begin{array}{l}\text { 1) Bancos de aforro e bancos de } \\
\text { aforro nas oficinas de correos } \\
\text { 2) Bancos comerciais } \\
\text { 3) Intermediarios financeiros non } \\
\text { bancarios }\end{array}$ \\
\hline Institucións semiformais: & $\begin{array}{l}\text { 1) Unións de crédito } \\
\text { 2)Cooperativas con múltiples } \\
\text { finalidades } \\
\text { 3) ONG. } \\
\text { 4) (Algúns) Grupos de autoaxuda }\end{array}$ \\
\hline Institucións informais: & $\begin{array}{l}\text { 1) Acredores individuais (puramente } \\
\text { dedicados a esta actividade) } \\
\text { 2) Os comerciantes, propietarios e } \\
\text { similares ( tales acredores individuais). } \\
\text { 3) A maioría dos grupos de autoaxuda } \\
\text { 4) Asociacións de aforro e crédito (grupos } \\
\text { de traballo, grupos de autoaxuda } \\
\text { multiusos) rotativas. } \\
\text { 5) As familias e os amigos }\end{array}$ \\
\hline
\end{tabular}

Táboa 3ạ.- Costes medio, morosidad y eficiencia de los microcréditos, según el Banco Grameen.

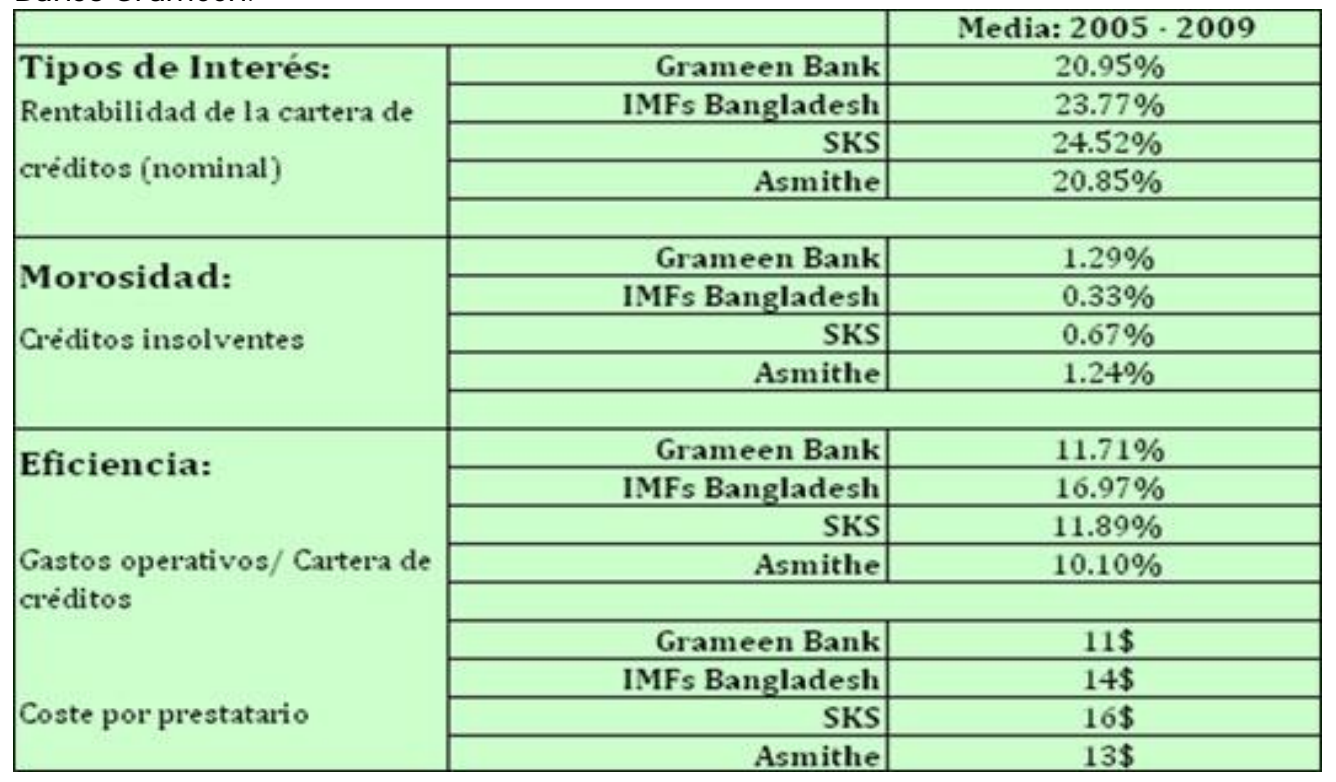

Revista Galega de Economia: http:/ / www.usc.es/ revistas/ index.php/ rge RGE at Ideas-Repec: http:// https:/ / ideas.repec.org/ s/ sdo/ regaec.html 